\title{
Reconceiving Resettlement Services as International Human Rights Obligations
}

\author{
Tom Clark
}

\begin{abstract}
The author draws on international treaties to argue that the provision of immigrant and refugee settlement services are human rights obligations. Therefore, services such as primary health care, food, education and housing are minimum core obligations that should be available to newcomers without discrimination. The implications of this position for advocacy initiatives are substantial. Instead of pleading for services from governments, activists, supported by international committees, would hold governments accountable for implementing international human rights treaties.
\end{abstract}

\section{Précis}

L'auteur s'appuie sur les traités internationaux pourétayer l'argumentation selon laquelle la mise en place de services favorisant l'intégration des immigrant et des réfugiées sur un territoire est une obligation relevant des Droits de l'Homme. Conséquemment des services comme les soins élémentaires de santé, la distribution de nourriture, $l$ 'instruction et le logement sont des obligations minimales fondamentales dues à tout nouvel arrivant sans discrimination. Plutôt que de quémander des services aux gouvernements, les activistes, appuyés par les comité internationaux, se doivent de tenir les gouvernements légalement responsables de l'application concrète des traités internationaux sur les Droits de l'Homme.

\section{Obligations_Significance of Rights}

This section examines the extent to which rights relating to social services are established in international juris-

Tom Clark, PhD, is a Research Fellow, Centre for Refugee Studies, York University, and Executive Director, Inter-Church Committee for Refugees, Toronto. prudence as applicable to all citizens and non-citizens under the jurisdiction of a State. It also notes the significance of the State obligation to "ensure" treaty rights "without discrimination." This paper draws on three generally established principles to interpret human rights treaties. The 1969 Vienna Convention on the Law of Treaties article 31 placed primary emphasis on the ordinary meaning of the text in context of the entire treaty, preamble, all other articles and any subsequent agreement. From this, international courts have established a practice of interpretation in the current juridical context. Texts of explicitly related subsequent agreements have interpretive power. They include human rights case law and jurisprudence as well as UN declarations and UN treaty texts not yet in force.

\section{Settlement Services and Ensuring Rights}

\subsection{Obligation to ensure rights without discrimination}

The author has shown elsewhere that CCPR article 2 requires a State Party to take thenecessary measures, including legislation, to ensure the rights in the CCPR without discrimination on any ground. The significance of the word ensure has been largely overlooked in international jurisprudence. It imposes a strong obligation. The CESCR contains a substantially similar obligation but allows discrimination by a "developing country" with respect to economic rights of non-citizens. However, for signatories of the CCPR, even this possibility falls under the freestanding right to non-discrimination in any right or benefit. And there is a legislative obligation from CCPR article 26 which requires that such nondiscrimination be in law. ${ }^{1}$ In the human rights case law of European and Inter-American Courts of Human Rights, "in law" and "laws" respectively means legislated.

\subsection{Newcomer services as measures \\ to remove discrimination}

Non-discrimination is itself a right, CCPR article 26 , and consequently requires the measures necessary to ensure it. This paper argues that settlement services are best viewed as measures required of a State to ensure non-discrimination. That is, settlement services are measures which offset the existing discrimination from disadvantage of the newcomer and allow the newcomer to enjoy rights and benefits on an equal footing with others. However, settlement services can also be viewed as a "benefit." This benefit must be provided without discrimination. That is, settlement services are themselves subject to the international doctrine of non-discrimination.

\section{Enjoyment of Civil and Political Rights}

The jurisprudence of the $\mathrm{UN}$ and other human rights treaty systems has evolved considerably since 1980 . In 1986, the UN Human Rights Committee, acting under CCPR article 40, issued General Comment 15[27] which clarified that in general non-citizens were to receive CCPR rights. ${ }^{2}$ The earlier Clark with Niessen paper shows that there has been much progress, but that even permanent resident non-citizens risk continuing problems in enjoying civil rights in several areas. ${ }^{3}$ Serious distinctions persist between permanent resident non-citizens and categories such as migrant worker and asylum seeker. Within its admissibility decision on Joseph $v$. Canada in the 1993 Annual Report, the Inter-American Commission notes that the Canadian Constitution applies to more than permanent resident non-citizens. 
CCPR rights set out in General Comment 15, apply to all newcomers.

\section{Enjoyment of Economic, Social and Cultural Rights}

The earlier Clark with Niessen paper shows that the implementation of the CESCR and regional human rights treaties for economic, social and cultural rights is less developed than that of the civil rights treaties. They are less widely ratified; the rights are not as precisely defined; there are weaker complaints mechanisms; there is less international case law; and the relevant committees have not focused much attention on non-citizens. For example, there is no counterpart to the HRC General Comment 15. Social and economic rights, like civil and political rights, are to be granted without discrimination. The main international text is the CESCR. Some of the obstacles to enjoying social rights in full equality are the same for civil and political rights. For example, there is ambiguity in the words "legally on the territory" which limits access to some rights for non-citizens who are deemed not to be legally on the territory. A second problem is that the imprecision in some of the social and economic rights makes them difficult to enforce. ${ }^{4}$

On the positive side, the UN CESCR Committee has developed a "minimum core obligation" of a State Party to "ensure minimum essential levels of each of the rights." A State Party in which any significant number of individuals is deprived of essential foodstuffs, or essential primary health care, of basic shelter or housing, or of the most basic forms of education is, prima facie, failing to discharge its obligations under the Covenant. ${ }^{5}$ One concludes that these economic and social rights, above others, must be accessible to everyone, including all categories of non-citizens. In CESCR General Comment 3 , the Committee also established a focus on certain rights which lend themselves to legal enforcement. Such rights are best enforced in combination with other rights such as CCPR article $26{ }^{6}$ From the perspective of settlement services, the selected important rights from the CESCR become special pointers to rights where it is particularly important to ensure newcomers can benefit on an equal footing. And there are similar signals from other human rights sources.

The OASCharter, drawing from the American Declaration of 1948, promises five social and economic rights without discrimination: leisure, social security, work under proper conditions with fair remuneration, education including equality of opportunity and free primary education, and the preservation of health. Health encompasses "sanitary and social measures relating to food, clothing, housing and medical care tot he extent permitted by public and community expenses." The more recent Pact of San Salvador, Additional Protocol to the American Convention in the area of economic, social and cultural rights incorporates an obligation for legislative measures and corresponding minimum thresholds for social security, education and health. For persons employed, social security must cover at least medical care and some form of benefit for accident or occupational disease (article 9.2), and essential health care must be made available to all individuals and families in the community (article 10.2.a). The Pact is not yet in force. However, for settlement service purposes, the Pact gives some indications as to significant social and economic rights which newcomers should be assisted to enjoy on an equal footing with others.

\section{The Promise of Non- Discrimination and Economic and Social Rights}

Jurisprudence on the general issue of non-discrimination under a human rights treaty has undergone major evolution during the $1980 \mathrm{~s}$. A doctrine and tests for non-discrimination emerged, especially in the European human rights system, butalso under the CCPR and, to a lesser extent, the OAS system. In 1989, the UN Human Rights Committee issued General Comment 18 on the matter. ${ }^{7}$ In 1990 Bayefsky com- pleted a thorough examination of the state of equality/non-discrimination in comparative international human rights law. ${ }^{8}$ Her study provides a useful framework for examining the extent to which international human rights treaty bodies have considered social, cultural and economic rights beyond CCPR rights and how they have permitted distinctions. CCPR article 26 is a free-standing right and General Comment 18 represents a highly significant clarification. Article 26 prohibits discrimination on any ground in the determination of any right in law-including social and economic rights. Indeed, pension rights have been litigated on equality grounds under the CCPR and the European Convention. It prohibits discriminatory effects of laws whatever their intent. It insists that similarly situated persons be treated equally. Under CCPR article 26 and under the somewhat similar European Convention on Human Rights article 14, issues of social rights such as pension entitlement, ${ }^{9}$ social security, ${ }^{10}$ and welfare ${ }^{11}$ can be litigated if they are provided in law. In Moustaquim v. Belgium the European Court of Human Rights applied the legal test to compare a non-citizen with citizens and to compare a non-citizen with another category of non-citizens. ${ }^{12}$ (However, this author believes the test was not applied correctly.) Thus Bayefsky's analysis reveals general criteria which test differences and these criteria extend to social rights and to comparisons among categories of non-citizens.

Combined with the two primary State obligations-measures to ensure rights and an effective remedy for a violation-these findings on non-discrimination may be summarized as follows:

1. States are to adjust laws and practices to ensure citizens and non-citizens enjoy rights or benefits without discrimination between citizen and non-citizen and among status or non-citizen

2. Legitimate differentiation between citizens and non-citizens and among categories of non-citizens 
must be: in law; objective; for a legitimate purpose under the CCPR; reasonable with respect of rights and other relevant aspects of the situations being compared, given the overall treaty aim of equality, and proportionate, at least in that there is no alternative which permits greater equality.

3. There must be a simple effective court remedy against discrimination per se in the awarding of any right or benefit.

In terms of the general theory of non-discrimination described by Clark with Niessen, a settlement service is a required measure to allow persons at a disadvantage, that is, persons who are in fact discriminated against, to enjoy especially those social and economic rights identified as particularly important on an equal footing with others. Evidently, orientation and referral are key measures if persons are to enjoy rights such as health care, shelter and to work related rights referred to above. For refugees, the paper argues below that family rights are a matter for affirmative non-discrimination.

The discrimination test regulates permitted differences among categories of newcomers with respect to access to this or that settlement service because a settlement service relates to one or more social or economic rights or benefits.

\section{Rights for Persons of Undetermined Status to the Extent Possible}

Generally, enumerated rights are accessible for persons allowed to enter a State party with a formal status: permanent resident; student; migrant worker; Convention refugee; Convention stateless person. While a State is exercising its jurisdiction over a person with respect to the determination of any one right such as liberty, the obligation remains to grant other rights to the extent possible. The concept of rights to the extent possible is inherent in the text of the CCPR, it is implicit in General Comment 15 and it is specifically stated with respect to the right to liberty in General Comment $21 .{ }^{13}$ This paper argues that in protracted proceedings to determine any one right, a non-citizen must be allowed to enjoy other rights such as liberty and the right to work, limited only by objective criteria which are generally applicable in that society. Persons who remain beyond six months should be allowed to have at least immediate family members, spouses and children, join them, as is indicated by the text adopted for the Convention on the Protection of all Migrant Workers and Members of their Families (Migrant Worker Convention). The Convention is not yet in force.

This analysis gives insights into the categories of newcomers who must be given settlement services if these services are to be given without discrimination. It also suggests a basis for arguing for legal recourse.

\section{Notes}

1. Torkel Opsahl, "Equality in Human Rights Law with Particular Reference to Article 26 of the International Covenant on Civil and Political Rights," in Progress in the Spirit of Human Rights, edited by Manfred Nowak, Dorothea Steurer, Hannes Trotter (Kehl/Strasbourg) Arlington: N.P. Engel Verlag, 1988), 51.

2. Tom Clark and Jan Niessen, "Equality Rights and Non-Citizens in Europe and America: The Promise, the Practice and Some Remaining Issues," NQHR 14, no. 3 (September 1996): 245-75.

3. Human Rights Committee, General Comment 15[27], The Position of Aliens under the Covenant, UN Doc. CCPR/C/21/ Rev.1, 19 May 1989, at 17.

4. E. W. Vierdog, "Legal Nature of the Rights Granted by the CESCR," (1978), 9 Neth.Y.B.Intl.L. 69 at 92-93.

5. UN CESCR Committee, General Comment No. 3 (1990), The Nature of States Parties Obligations, UN Doc. E/1991/23 (1991), E/C.12/1990/8, Annex III, at 83, at paragraph 8 .

6. Martin Sheinin, "Direct Applicability of Economic Social and Cultural Rights: A Critique of the Doctrine of Self-Executing Treaties," in Social Rights as Human Rights: A European Challenge, edited by Krzysztof Drewicki, Catarina Kraus, and Allan Rosas (Institute for Human Rights, Abo Akademi University, 1994), 73.

7. The term "discrimination" as used in the [CCPR includes] any distinction, exclu- sion, restriction or preference which is based on any ground such as race ... birth or other status, and which has the purpose or effect of nullifying or impairing the recognition, enjoyment or exercise by all persons, on an equal footing, of all rights and freedoms. Not every differentiation of treatment will constitute discrimination if the criteria for such differentiation are reasonable and objective and if the aim is to achieve a purpose which is legitimate under the Covenant. The law shall guarantee ... effective protection against discrimination. Human Rights Committee, General Comment 18, Non-discrimination, UN Doc. CCPR/2/ 21/Rev.1/Add.1, November 1989.

8. The European Commission and Court of Human Rights have formulated criteria for distinguishing justified and unjustified distinctions. Decisions such as Lithgow and others v. UK, 1986 of the European Court establish that persons in analogous situations should be treated equally. However, the application of the criteria has not always been followed. The UN Human Rights Committee has applied essentially this definition of a legitimate distinction in a number of its communications. The Inter-American Court has approved this approach. Anne F. Bayefsky, "The Principle of Equality or Non-Discrimination in International Law," (1990), 11 HRLJ 1, at 12, 14.

9. Dietmar Pauger v. Austria, Communication No. 415/1990, Views 1992, UN Doc. $\mathrm{A} / 47 / 40$.

10. S. W. N. Broeks v. Netherlands, Communication No. 172/1984, Views 1987, S. $H$. Zwaan de Vries v. Netherlands, Communication No. 189/1984, Views 1987, UN Doc. A/42/40, (1987) at 151,160.

11. Salesi v. Italy (1993), European Court of Human Rights, ECHR Ser. A. 257E.

12. Moustaquim v. Belgium, European Court of Human Rights, Ser. A 193, 18 November 1991.

13. Persons deprived of their liberty enjoy all the rights set forth in the Covenant, subject to the restrictions that are unavoidable in a closed environment. Treating all persons deprived of their liberty with humanity and with respect for their dignity is a fundamental and universally applicable rule. This rule must be applied without distinction of any kind. Human Rights Committee, General Comment No 21(44), Article 10, UN Doc. CCPR/C/21/ ,Rev.1/Add.3, 1992 at paragraph 3, 4.

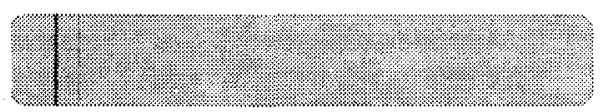

